\title{
Do Job Disamenities Raise Wages or Ruin Job Satisfaction?
}

\author{
Petri Böckerman \\ Labour Institute for Economic Research \\ and \\ Pekka Ilmakunnas \\ Helsinki School of Economics and HECER
}

Discussion Paper No. 20

September 2004

ISSN 1795-0562

HECER - Helsinki Center of Economic Research, P.O. Box 17 (Arkadiankatu 7), FI-00014 University of Helsinki, FINLAND, Tel +358-9-191-28780, Fax +358-9-191-28781, E-mail info-hecer@helsinki.fi, Internet www.hecer.fi 


\title{
Do Job Disamenities Raise Wages or Ruin Job Satisfaction?*
}

\begin{abstract}
This study investigates the role of adverse working conditions in the determination of individual wages and overall job satisfaction in the Finnish labour market. The potential influence of adverse working conditions on self-reported fairness of pay at the workplace is considered as an alternative, indirect measure of job satisfaction. The results show that working conditions have a very minor role in the determination of individual wages in the Finnish labour market. In contrast, adverse working conditions substantially increase the level of job dissatisfaction and the perception of unfairness of pay at the workplace.
\end{abstract}

JEL Classification: J28, J31.

Keywords: compensating wage differentials, job satisfaction, working conditions.

Petri Böckerman

Labour Institute for Economic Research

Pitkänsillanranta $3 \mathrm{~A}$

FI-00530 Helsinki

FINLAND

e-mail: petri.bockerman@labour.fi
Pekka Ilmakunnas

Department of Economics

Helsinki School of Economics

P.O. Box 1210

FI-00101 Helsinki

FINLAND

e-mail: pekka.ilmakunnas@hkkk.fi

* This study has been financed by The Finnish Work Environment Fund (Työsuojelurahasto). We are grateful to Mika Haapanen, Kari Hämäläinen, Reija Lilja and Roope Uusitalo for comments. The usual disclaimer applies. 


\section{Introduction}

The idea that workers should be compensated for a number of adverse working conditions is almost as old as the profession of economics itself. This perspective on the functioning of labour markets originates from the writings of Adam Smith and was later formulated as the theory of compensating wage differentials (see e.g. Brown 1980; Rosen 1986; Dorman 1996). The theory states that workers receive wage premia related to harms and hazards at their workplace and utilities of workers are therefore equalised between industries and occupations by means of competition in the labour market. In particular, the theory implies that the marginal worker receives a compensated wage just enough to accept the work conditions, whereas those who are not risk averse or do not mind adverse conditions are paid more than is necessary to have them work in jobs that are risky or have bad working conditions.

Empirical studies on compensating wage differentials have applied several different measures for job disamenities. An extensive literature exists on the wage effects of work-related accidents, for example, based on industry-level or occupation-level aggregates (see Viscusi and Aldy 2003, for a survey). Another branch of the literature focuses on adverse working conditions from a broader perspective, including physical demands, noise, dirtiness, etc. by using hedonic wage equations (see e.g. Brown 1980). In recent research, for example, job stress (French and Dunlap 1998), flexible working hours (Gariety and Shaffer 2001), shift work (Lanfranchi, Ohlsson and Skalli 2002), and perception of job instability, measured by product market volatility (Magnani 2002), among other factors, have been investigated.

Overall, the evidence is fairly mixed. Perhaps the clearest result in this field of research is that the risk of death at the workplace has some positive influence on individual wages (see e.g. Viscusi and Aldy 2003), but there is some empirical evidence that shows that compensating wage differentials are also related to other job disamenities. In addition, there is evidence of compensating wage differentials from a number of countries that have different institutional frameworks for labour markets. On the other hand, there are several empirical studies that do not support the hypothesis of compensating wage differentials. For example, Brown (1980) used longitudinal data in order to control for more worker characteristics than had been 
common in the earlier literature. The omitted-variable bias has been a serious problem in most of the empirical studies that have tried to estimate the magnitude of compensating wage differentials. Even with this approach, the coefficients of various adverse job characteristics were often wrong-signed and insignificant in the wage equations.

There have been studies that aim to provide alternative explanations for wage differentials across industries and occupations that may explain the rejections of the hypothesis of compensation differentials. In this respect, Dorman and Hagstrom (1998) stress that the non-competitive aspects of wage formation are very important in terms of compensating wage differentials. This means that the estimated wage equation should include a number of industry-level controls (such as profitability and capital/labour ratio) or, alternatively, a full set of dummies attached to industries. They discover that the inclusion of industry-level controls largely wipes out the compensating wage differentials that have been discovered in the literature. This pattern is consistent with the dominance of non-competitive wage formation in the labour market.

Other econometric issues that may be essential for observing compensating wage differentials include the selectivity of workers into risky workplaces and the endogeneity of work conditions (e.g. Sandy and Elliott 1996, Daniel and Sofer 1998, Wei 1999, Arabsheibani and Marin 2001). The reason is that more dangerous jobs tend to be chosen by those workers who are less averse to dangers at the workplace. This implies that the OLS estimates of job disamenities based on the wage equation may be downwards biased. ${ }^{1}$

There are theoretical reasons for expecting that adverse working conditions may not be reflected in wages. Hwang, Mortensen, and Reed (1998) and Lang and Majumdar (2003) obtain this conclusion by constructing search models in which jobs vary with respect to non-pecuniary characteristics. The equilibrium distribution of wage and job characteristic combinations need not show evidence of compensating wage differentials. In addition, Manning (2003) strongly argues that utilities of workers are not equalised between industries and occupations in the labour market characterized 
by frictions and monopsony power by employers. Frictions in worker mobility can prevent the market for disamenities from reaching equilibrium.

The large literature on job disamenities has almost solely focused on pecuniary rewards for adverse working conditions. However, there is an emerging empirical literature that aims at understanding the determination of overall job satisfaction in relation to adverse working conditions. This interest has, for the most part, arisen owing to inconsistencies in the results of earlier studies and enduring scepticism regarding the existence of competitive labour markets and compensating wage differentials.

The level of job satisfaction reported by workers may, indeed, have been affected by various job disamenities. This pattern has been disclosed in several recent studies. ${ }^{2}$ Godechot and Gurgand (2000) investigate the determination of individual wages and job satisfaction in France. Their results indicate that adverse working conditions tend to have some negative effect on job satisfaction. For instance, workers that fail to have enough opportunities for breaks report a lower level of job satisfaction, but they do not get higher wages as a compensation for their adverse working conditions. Webster and Bainger (2001) focus on the non-pecuniary aspect of job choice by applying International Social Science Surveys for Australia. They discover that nonpecuniary aspects are important in job choice, for instance, for women with children under 18 years of age. Kawaguchi (2002) reports, based on the National Longitudinal Survey of Youth (NLSY), that self-employed persons are more satisfied, which can be understood as a compensation for their lower income. Lalive (2002) investigates the determination of individual wages and job satisfaction by using NLSY. The results show that wage differentials do not exclusively compensate for work conditions. By using the German Socio-Economic Panel Study Stutzer and Frey (2003) document that commuters report a lower level of subjective well-being, but they do not get higher wages in response to this, other things being equal. Finally, Clark (2003) puts forward the argument based on the British Household Panel Survey that high-paying occupations are also high satisfaction occupations. This observation is inconsistent with the existence of compensating wage differentials in the labour market. In addition to these studies, there is research where the worker's level of job satisfaction is inferred indirectly e.g. through the probability of switching industries. Herzog and 
Schlottmann (1990) compare the coefficients of the wage equation and the job change equation in order to learn insights about the extent of compensating wage differentials for job risks in the U.S. manufacturing industries.

This empirical study contributes to the literature on compensating wage differentials and job satisfaction in three ways. First, there are no earlier estimates available about the existence and the magnitude of the compensating wage differentials in the Finnish labour market. ${ }^{3}$ The Finnish case is interesting, because the binding collective labour agreements already contain some compensation for adverse working conditions. In particular, the collective labour agreements contain pecuniary compensations for uncomfortable working hours. For instance, there are specific compensations for the 3-shift workers. However, the collective agreements put only an effective floor to wage levels in particular occupations (or jobs). There is no upper limit for wages as such. In addition, the collective labour agreements adjust quite slowly to take into account the changes in general working conditions and they cannot account for all specific working conditions in different firms. In other words, the heterogeneity of workplaces makes it hard for collective agreements to take into account all the relevant aspects of working conditions that may matter for individual workers. Therefore, there is still room for additional monetary compensation, because workers' subjective valuations about their working conditions can differ greatly from the ones that have been stipulated in the collective agreements by the central organizations of employees and employers.

Second, the Finnish data make it possible to investigate the impact of a broad range of working conditions on individual wages and overall job satisfaction. Most of the earlier empirical studies on compensating wage differentials and job satisfaction have used only a very limited set of variables that are used to describe work disamenities. Moreover, the high unemployment rate (12.7 per cent in 1997, the year of our data) may constitute an obstacle to the formation of compensating wage differentials by reducing the bargaining power of individual workers in the labour market. In particular, this makes it more likely that workers report a lower level of overall job satisfaction in jobs with adverse characteristics. 
Third, in addition to overall job satisfaction, we investigate an alternative, indirect measure of satisfaction by considering the potential influence of adverse working conditions on self-reported fairness of pay. Recently, fairness standards have been stressed in a number of studies on labour markets (e.g. Fehr and Gächter 2000), but these issues have not often been related to the literature on job disamenities. In this respect, consideration of fairness of pay completes the picture painted by adverse working conditions on workers' satisfaction.

This study is structured as follows. Section 2 contains considerations on an empirical strategy to test compensating wage differentials. Section 3 provides a description of the data and Section 4 contains the estimation results for wage equations and job satisfaction equations (including an alternative, indirect measure for satisfaction based on fairness of pay). Section 5 concludes the paper.

\section{Empirical strategy}

We discuss here some approaches for testing compensating wage differentials that do not rely solely on the estimation of a hedonic wage equation, but also apply information on job satisfaction. Assume that the utility of an individual depends on wage ${ }^{4}$ and working conditions: $U=U(w, D)$, where $\mathrm{w}$ is wage and $D$ a vector of measures of disamenities related to work; it is assumed that $\partial U / \partial w=U_{w}>0$ and $\partial U / \partial D_{i}=U_{D i}<0$ for all disamenities $i$. On the other hand, if the disamenities are compensated in the form of higher wages, we have $w=w(X, D)$ with $2 w / \partial D_{i}=w_{D i}>$ 0 for all $i$. The vector $X$ includes all other determinants of wages, such as education and experience. Inserting the wage equation in the utility function gives $U=$ $U(w(D, X), D)$. Full compensation of disamenities implies that, in the margin, the working conditions do not affect utility, i.e. $d U=U_{w} w_{D i} d D_{i}+U_{D i} d D_{i}=0$, for all $i$. This finally gives $w_{D i}=-U_{D i} / U_{w}$. That is, the marginal compensation of an adverse working condition in terms of wage has to equal the marginal rate of substitution of wage and the particular disamenity. In a competitive labour market, would also be the trade-off in terms of firms' profits between wage and working conditions would be equal to the slope of the wage equation. 
Empirically, the analysis of compensating wage differentials proceeds by estimating a standard wage equation with the usual control variables $X$. The model is augmented with variables that capture, in broad terms, the workers' subjective views about the factors of harms and hazards in their current working conditions. Most of the literature on compensating wage differentials has tested their existence on the basis of this kind of hedonic wage equations. However, the estimates of the effects of disamenities on wages give the marginal rate of substitution between wages and disamenities only for those workers and firms that have chosen that particular level of disamenities (see e.g. Rosen 1986).

To test whether the marginal rates of substitution are, in fact, equal to the slope of the wage equation, we estimate another equation that measures in some way the utility derived from wage and disutility caused by the disamenities. Based on the estimated parameters of these equations, it is possible to make conclusions on whether adverse working conditions are compensated either by the collective labour agreements or by firm-level wage formation.

Measurement of utility is by no means a trivial task. A natural alternative is overall job satisfaction (or dissatisfaction) (e.g. Clark 2003). It is typical feature of workplace surveys that job satisfaction is expressed in an ordinal scale with a few (often 3-5) alternatives. This is also the case with the data that we are using. This kind of data calls for modelling the utility equation using ordered probit or logit estimation. Although the variable to be explained is not continuous and, hence, the coefficients cannot be directly compared with those from the estimation of an equation for a continuous wage, the test of compensating wage differentials requires only the ratio of the coefficients of wage and a disamenity. Naturally, econometric issues like selectivity may have to be dealt with. Note that if dissatisfaction rather than satisfaction is measured, the signs of the derivatives above are reversed, i.e. $U_{D i}>0$ and $U_{w}<0$.

The nature of wage formation can further be evaluated by taking advantage of information about workers' perception about the fairness of pay. This constitutes a direct measure of utility derived from wage. Again, this is available as an ordinal variable. As still another alternative, we could use quit intentions on the grounds that 
lower quit intentions imply higher satisfaction with the current job. Herzog and Schlottman (1990) use this approach for comparing wage and indifference curve slopes and Gronberg and Reed (1994) estimate the marginal willingness to pay for job attributes by taking the ratio of the coefficients of job disamenities and wage in a job duration model.

To interpret the test, consider first the case that adverse working conditions have no or only a small impact on individual wages, but have an adverse impact on the level of job satisfaction and the perception about the fairness of pay (and, in addition, wage yields positive job or pay satisfaction), i.e. $0 \leq w_{D i}<-U_{D i} / U_{w}$. Then the conclusion is that adverse working conditions are not sufficiently compensated in terms of higher wages. In other words, workers' inherent aspirations for higher wages in adverse working conditions are not transformed into higher actual wages.

It is possible that adverse working conditions have no impact on wages or the level of job satisfaction, $w_{D i}=-U_{D i} / U_{w}=0$. Then it can be concluded that adverse working conditions are not such a factor that should be compensated in the labour market. If adverse working conditions may have an impact on individual wages, but not at all or only little on the level of job satisfaction, $w_{D i} \geq-U_{D i} / U_{w} \geq 0$. This would imply overcompensation for adverse working conditions. Finally, equality $w_{D i}=-U_{D i} / U_{w}$ is consistent with the hypothesis that the wage formation fully takes into account adverse working conditions and the marginal rates of substitution between wage and working conditions are therefore equalised in the labour market, as stated by the theory of compensating wage differentials.

There are alternative ways of testing for compensating wage differentials. If utility depends on wage and disamenities, and wage fully reflects compensation for the working conditions, then inserting the implied wage in the utility function should wipe out the disamenities, but also the wage. This is easily demonstrated in the linear case $U=\alpha+\beta D+\delta w+X \gamma$ and $w=\theta+\phi D+Z \rho$, where $U$ is measured by job satisfaction and $X$ and $Z$ denote all other variables. Compensating wage differentials implies that $\phi=-\beta / \delta$. Applying this in the wage equation and inserting the wage equation into the utility function gives $U=\alpha+\delta \theta+X \gamma+Z \rho \delta$. Then a test of the 
compensating wage differentials would be a test of whether the hypothesis $\beta^{*}=0$ holds in the job satisfaction equation $U=\alpha^{*}+\beta^{*} D+X \gamma+Z \rho^{*}$, where wage is not included. This is the testing strategy employed by Godehot and Gurgand (2000) and Stutzer and Frey (2003). Compensating wage differentials can also be tested by testing the hypothesis $\delta=0$ in the job satisfaction equation $U=\alpha^{*}+\delta^{*} w+X \gamma+Z \rho^{*}$ where disamenities are not included. This test is applied by Lalive (2002). Clark (2003) also uses an approach that is based on the above simple model. He explains both job satisfaction and wages with occupation dummies. A difficulty with these tests is that in the case of multiple work-related harms and hazards, it has to be assumed that compensating wage differentials apply to all of them at the same time.

If there are no variables that can be used as proxies for utility, it is possible to test the predictions of compensating wage differentials by estimating the wage equation and an equation that is derived from the optimization condition for utility maximization. Their slopes should be the same if the hypothesis of compensating wage differentials holds. This approach is discussed, for example, in Viscusi (1993). Finally, if the purpose is not to test for compensating wage differentials but rather to assess their magnitude, the use of the optimization condition is possible. Alternatively, if job satisfaction data is available, one can estimate the model with wage included and indicators for workers in different kinds of working conditions. The monetary value of disamenities (or amenities) can then be assessed from the coefficients. Kawagushi (2002) uses this method for analyzing the amenity value of being self-employed, compared with salary earners.

\section{Data}

The data set that we are using in this study is the Quality of Work Life Survey (QWLS) of Statistics Finland. It is conducted at irregular intervals, the latest being from 1997, which is the year that we use. The initial sample for QWLS is derived from a monthly Labour Force Survey (LFS) of Statistics Finland, where a random sample of the working age population is selected for a telephone interview. The 1997 QWLS was based on LFS respondents in September and October who were 15-64 year old wage and salary earners with a normal weekly working time of at least five 
hours. 3795 individuals were selected for the QWLS sample and invited to participate in a personal face-to-face interview. Out of this sample, 2978 persons, or around 78 per cent, participated (see Lehto and Sutela 1999). Owing to missing information on some variables for some workers, the sample size used in estimations varies by equation and is around 2750 observations.

For our research, a major strength of the QWLS survey is that it contains a number of questions about the subjective views of workers with respect to their working conditions (including factors of perceived harms and hazards in broad terms). ${ }^{5}$ This means that the QWLS survey is highly suitable for the investigation of compensating wage differentials in the Finnish labour market. The survey also contains information about the level of overall job satisfaction, considerations for fairness of pay and notions about the promotion prospects, among many other things. In addition, QWLS includes a number of questions on the personal characteristics and work experience of the respondents that can be used as control variables.

Statistics Finland supplements QWLS with information from the LFS on, for example, working time and exact labour market status. Supplementary information on the industry and location of the employer, and on the level and field of education of the respondents, is gathered from various registers maintained by Statistics Finland. The variables that we are using are described in detail in Appendix 1, and Appendix 2 reports descriptive statistics for the explanatory variables included.

We have two alternative measures for wages. The first, WAGE, is the logarithm of hourly earnings that have been calculated from annual taxable earnings obtained from tax registers divided by annual hours, which, in turn, are based on regular weekly hours from LFS. An alternative measure, WAGECAT, is based on self-reported monthly wage groups. The variable is the logarithm of the lower limit of the groups.

We measure job dissatisfaction with the variable DISSATISFACTION, which is an ordered discrete variable with 4 categories, 1: very satisfied (the number of observations in this category is 880), 2: quite satisfied (1813), 3: rather dissatisfied (152), and 4: very dissatisfied (29). Since this measures disutility, the signs of $U_{D}$ and $w_{D}$ as discussed in section 2 are reversed. As an alternative dissatisfaction measure we 
use the PAYUNFAIR variable, which is an ordered discrete variable with 5 categories, 1: the wage is clearly higher than it should be (the number of observations in this category is 8), 2: the wage is somewhat higher than it should be (53), 3: wage is about right (1269), 4: the wage is somewhat lower than it should be (1055), and 5: the wage is clearly lower than it should be (543). As expected, there are only a few observations in the first categories.

This study takes a different angle from that of most of the earlier literature, because the empirical investigation of compensating wage differentials and the level of job satisfaction is based on an application of the subjective valuation of adverse working conditions that are related to wages and job satisfaction at the unit of analysis. Indeed, Viscusi and Aldy (2003) in their survey of the literature on compensating wage differentials point out that very few empirical studies have actually compiled workers' subjective perceptions regarding risks at the workplaces. For instance, Clark (2003) uses occupation dummies to pick out the job disamenities faced by British workers.

The subjective valuations of harms and hazards related to working conditions are measured in the QWLS survey by the use of different categories. For perceived harms, there is a five-point scale in which the highest category corresponds to the perception by the worker that a feature of working conditions is 'very much' an adverse factor at the workplace. For perceived hazards, the highest category among three possibilities is the one in which the respondent considers a feature at the workplace 'a distinct hazard'. Responses to the questions about adverse working conditions can be aggregated by forming a dummy variable that equals one if there is at least one clearly adverse factor (HARM) and a dummy that equals one if there is at least one distinct hazard (HAZARD). These variables capture different aspects at Finnish workplaces, as implied by the relative small correlation of 0.31 that prevails between these two key variables that are used to describe adverse working conditions.

We use the following dummy variables as other job disamenities. UNCERTAINTY tells us that there is at least one clear insecurity factor at the workplace, NOVOICE implies that there is at least one aspect of the work that the worker cannot influence at all, NEGLECT is a dummy for the existence of at least one aspect where the worker gets no support from superiors, ATMOSPHERE tells us that the worker experiences 
at least one negative aspect in the work atmosphere almost daily, and CONFLICTS is a dummy for at least one type of conflict often experienced often at the workplace. Additionally, we have dummy variables for the difficulty of taking breaks (NOBREAK), for working mostly outdoors (OUTDOORS), and physically or mentally very demanding work (HEAVYPHYSIC and HEAVYMENTAL, respectively).

We include a large set of control variables. There are typical human capital variables that are sex (FEMALE), age (dummies AGE_1 to AGE_3), union membership (UNION), marital status (SINGLE), a dummy for a working spouse (SPOUSEWORK), number of children (CHILDREN), level of education (dummies EDU_1 to EDU_4), and field of education (dummies EDUHUM, EDUBUS, EDUTECH, EDUCARE). In addition, we include variables that capture the occupation and job switches (OVER1PROFS and SWITCHES, respectively), the unemployment history of a worker (dummies UMOS_1 to UMOS_4), tenure (TENURE and TENURE ${ }^{2}$ ) and a dummy for second job holders (SECONDJOB).

There are dummy variables that describe the payment system (FIXEDPAY, PIECERATE) and dummies for working time related aspects of work, like temporary contract (TEMPORARY), part-time work (PART_TIME), night work (NIGHT), shift work (SHIFT), weekend work (WEEKEND), and overtime almost daily (MUCHOVERTIME). Other dummies give an indication of the use of computers (MUCHCOMPUTER), poor advancement opportunities (NOPROMOTION), discrimination at the workplace (DISCRIMINATION), teamwork (HIGHTEAM), team-related problems (TEAMPROBLEM), and managerial tasks (MANAGER). Onthe-job training is measured by the number of days in training (DAYSTRAINING).

There is some information available on the health of the worker, especially, number of absences (SICKABSENCE) and self-assessment of work capacity (CONDITION, on a scale 0 to 10). Information on the employer includes dummies for the public sector and foreign private owners (PUBLIC, FIRMFOREIGN), and plant size group (dummies PSIZE_1 to PSIZE_4), and a dummy for employment growth (EMPGROWTH), unstable financial situation (FIRMUNSTABLE), and a high share of female workers (FEMSHARE). Finally, we include industry dummies (14 
industries), occupation dummies (81 occupations), and the regional unemployment rate (UN) for capturing the possible regional variation in the wage level and the level of job satisfaction reported by workers.

\section{Estimation results}

\subsection{Basic results}

The wage equation is estimated with OLS with the logarithm of wage, WAGE, as the dependent variable (Table 1, Column 1). Wage is explained with typical human capital variables, work history variables, job characteristics, firm characteristics, and job disamenities. We concentrate here on the working conditions and discuss the other results very briefly. The results show some empirical evidence for compensating wage differentials arising from uncomfortable working hours. Workers that are engaged in 3-shift work get around 19\% higher hourly wages. This particular finding is not surprising as such, because higher wages for the 3-shift workers are stipulated in the binding collective labour agreements. In addition, those workers that work mostly outdoors get around 13\% higher hourly wages in compensation for their adverse working conditions. However, there fails to be empirical evidence for the existence of compensating wage differentials arising from various perceived harms and hazards.

\section{$===$ TABLE 1 HERE $===$}

There are some explanatory variables included to capture adverse working conditions that are wrong-signed. This has actually been a typical finding in the literature on compensating wage differentials (see e.g. Brown 1980). For instance, workers with no voice at their workplace (i.e. they cannot influence their work) suffer from lower wages. In addition, workers located at workplaces in which there is at least one negative aspect in the work atmosphere have lower wages. The theory of compensating wage differentials predicts exactly the opposite. All in all, the results support the perspective that working conditions have a very minor role in the determination of individual wages in the Finnish labour market. There seem to be no pecuniary rewards for adverse working conditions. 
We briefly summarize the results on the control variables included in the wage equation. In broad terms, the coefficients get the expected signs and they are in line with the literature. Females get around 19\% lower hourly wages. Both age and educational level increase wages. What is more puzzling is the existence of substantial union premium despite the high rate of trade union density (around $80 \%$ of the salaried labour force). Workers suffer substantial wage losses from being unemployed during the previous five years. The largest effects arise from being unemployed over 25 months. These effects are in line with the empirical evidence on job displacements (see e.g. Kletzer 1998). Tenure yields decreasing returns. The estimated peak in the wage profile in terms of tenure is at around sixteen years of service in the same company. Workers with temporary contracts get lower wages, but this pattern fails to extend to part-time workers. The use of computers does not yield a wage premium. There is some evidence that workers that have recently participated in on-the-job-training get higher wages. Managers enjoy higher wages. Wages are not lower in the public sector or in foreign-owned companies, other things being equal. However, wages are substantially higher in large plants, which is in line with a wellknown stylized fact of the literature (see e.g. Oi and Idson 1999). There is some evidence for the so-called wage curve, as documented by Blanchflower and Oswald (1995). In other words, wages seem to be lower in regions with high unemployment. The pattern that wages are lower in regions with high regional unemployment is exactly opposite to the prediction of compensating wage differentials that would imply that wages are higher in regions with high unemployment for compensating workers for the higher average risk to become an unemployed person in those particular labour markets.

Clearly the results speak against compensating wage differentials. Workers' inherent aspirations for higher wages in adverse working conditions are not transformed into higher actual wages in the labour market. A possible reason for this is the high unemployment rate (12.7 per cent in 1997, the year of our data), which constitutes an obstacle for the formation of compensating wage differentials by reducing the bargaining power of individual workers, thereby making it more likely that workers report lower levels of job satisfaction in jobs with adverse working conditions. Unemployment may also reduce overall opportunities for improving job satisfaction through job changes. ${ }^{6}$ 
The job dissatisfaction equation is estimated with ordered Probit. To account for the possible endogeneity of wage, we use the fitted wage as an explanatory variable and exclude the work history variables (OVER1PROFS, SWITCHES, UMOS1-UMOS4) from the job dissatisfaction equation. The results reveal that adverse working conditions substantially increase the level of job dissatisfaction reported by workers (Table 2, Column 1). Not having enough breaks, strongly experiencing at least one kind of harm or uncertainty, lack of voice, feel of neglect, bad atmosphere, mentally or physically heavy work, lack of promotion prospects and discrimination at the workplace all increase job dissatisfaction. Since the disamenity variables are either insignificant or wrong-signed in the wage equation, and, on the other hand, the fitted wage is not significant in the job satisfaction equation, there is no need to compare the coefficients directly in the way suggested in Section 2.

$===$ TABLE 2 HERE $===$

The job dissatisfaction equation reveals that the fitted wage has no impact on overall job satisfaction. Females report higher levels of job satisfaction. Older workers are also more satisfied. Singles are less satisfied, and workers whose spouse is working report lower levels of job satisfaction. Education has no significant effects. An increase in tenure eventually yields a decrease in the level of job dissatisfaction. The estimated peak in the job dissatisfaction profile in terms of tenure is at around eight years of service in the same company. The most likely explanation for this observation is that those workers that are dissatisfied with their matches gradually move away from the companies in which they are currently located (see e.g. Freeman 1978). The 3-shift workers are more satisfied. In addition, workers performing a great deal of paid overtime are more satisfied. The reason for this is most likely that those particular workers are more motivated and therefore more committed to their work. Workers with good health are more satisfied. There is no statistically significant variation in workers' job satisfaction in terms of the size of a plant despite the fact that the level of job satisfaction is usually observed to be higher in small plants (see e.g. Clark 1996). However, workers located in companies with financial difficulties report lower levels of job satisfaction, which may be related to a perceived fear of job loss. 
The equation estimated for the perception of unfairness of pay reveals that prime-age workers are more dissatisfied with their pay in comparison with the remuneration paid in other occupations. Workers that belong to trade unions are also more dissatisfied. The perception of unfairness of pay is more common for workers with temporary contracts. In addition, workers that perform a great deal of overtime are more dissatisfied despite the fact that there is a substantial overtime premium in the labour market. $^{7}$ Workers located in foreign-owned companies are more satisfied. Workers that are employed in large plants are less dissatisfied with their pay in comparison with the remuneration paid in other occupations. In contrast, workers that are currently located in companies that face financial difficulties are more dissatisfied with their pay.

\subsection{Robustness of the reported results}

We start the discussion about robustness of the conclusions from various alternative specifications of the wage equation. We estimated the wage equation without the employer characteristics. This is motivated by the argument that, in competitive labour markets, employer characteristics, such as plant size, should not be statistically significant explanatory variables for individual wages (see e.g. Manning 2003). This particular specification of the wage equation is therefore more consistent with the theory of compensating wage differentials, which is based on the premise of competitive labour markets. The estimation (results not reported) yields essentially the same results concerning the insignificant role of adverse working conditions in the determination of individual wages in the Finnish labour market. Including both the employer characteristics and occupational dummies did not change the results either (Table 1, Column 2).

Estimation results of the wage equation separately for females and males reveal that males who do not have enough opportunities for breaks at their workplace get around $26 \%$ higher hourly wages, other things being equal (Appendix 3 ). However, there is definitely no empirical evidence for the corresponding compensating wage differentials for females. Otherwise, the results again show no signs of compensating differentials. 
We also experimented with alternative definitions of the disamenity variables. In our basic definition of perceived harm and hazard dummies the variables are equal to one if the worker reports at least one adverse factor at the workplace (see Appendix 1). This definition of perceived harms and hazards can be made tighter by requiring that there must be at least three clearly adverse factors at the workplace. In this case the average values for the HARM and HAZARD variables are around 0.05, in comparison with the values 0.29 and 0.34 , respectively, in the basic definition. However, using these new dummy variables does not change the earlier conclusion about the role of adverse working conditions in the determination of individual wages (results not reported). In addition, we did take a sum of the adverse job characteristics in the calculation of the HARM and HAZARD variables. In this specification of the wage equation, the coefficient for the HARM variable turned out to be positive at the $10 \%$ significance level (not reported). Otherwise, the results remained the same.

Instead of the continuous wage variable we used a self-reported categorical wage variable (WAGECAT) and estimated the model with interval regression (Table 1, Column 3). This gives a significant positive coefficient for night and shift work, whereas only shift work was significant for the continuous wage variable. ${ }^{8}$ Mentally heavy work and team work related problems also obtain positive and significant coefficients. Otherwise, there are no indications on compensation for working conditions. Some of the control variables such as MUCHCOMPUTER seem to obtain significance when the categorical wage variable is used.

Next, we discuss some robustness tests for the job satisfaction model. Using the actual wage in the job satisfaction model estimated with ordered Probit gives very similar estimation results (not reported) as the model with the fitted wage. Using the "wage gap" (difference of actual and predicted wage) instead of the fitted wage in the job satisfaction model does not change the conclusions (not reported). Since there are relatively few observations in the highest job dissatisfaction categories, we also tried aggregating categories 3 and 4 . This did not change the results (not reported).

We also tried wage dissatisfaction as an alternative to overall job dissatisfaction. The main difference to the model with job satisfaction is that now perceived job hazards have a significant positive effect on the feeling of the unfairness of pay (Table 2 , 
Column 2). There are changes in the significance of some of the control variables, too. Replacing the fitted wage by actual wage in the PAYUNFAIR equation or aggregating categories 1 and 2 (highest satisfaction with wage) did not change the results (not reported). Moreover, using "wage gap" (difference between actual and predicted wage) instead of the fitted wage in the model for the unfairness of pay at the workplace does not change the conclusions (not reported). In addition, we did make some experiments with semi-nonparametric ordered Probit models (Stewart, 2004; results not reported). In the job dissatisfaction equation, the explanatory variables that capture adverse working conditions turned out to be statistically insignificant, although they did get the same signs as in the basic version of the equation. For the PAYUNFAIR equation, the results for the impact of adverse working conditions remained the same and also statistically significant.

The failure to observe compensating wage differentials may be due to the selectivity of workers for particular workplaces. In this sense, working conditions self-reported by workers are at least partly chosen by those very same workers. At least, in principle, the impact of the selectivity of workers for their working conditions from the point of view of the estimates of compensating wage differentials can be evaluated by estimating models in which working conditions are in the first-stage of estimation explained by the personal background variables and the past labour market experience of workers by the use of Probit models. By taking into account the selectivity of workers for workplaces, individual hourly wages can, in the second-stage of estimation, be explained by the same variables as in Table 1 .

Experiments with Probit models indicate that there is a tendency that workers with more education, particular fields of education (business, law or social science) and workers with little work experience with their current employer have a smaller probability of self-reporting perceived harms and hazards at their workplaces (results not reported). The results provide some support for the argument that the OLS estimates for compensating wage differentials may be downwards biased. However, since we have a large set of variables that describe adverse working conditions, dealing with selectivity in many dimensions would be extremely difficult. For this reason, these conclusions should be regarded as tentative. 
As a final robustness analysis we tested for compensating wage differentials by two alternative ways outlined in Section 2. That is, we estimated two job dissatisfaction equations where, in the first one, only the wage (and control variables) were included, but no work disamenities, and, in the second, work disamenities (and control variables) were included, but no wage (not reported). The same was repeated for wage dissatisfaction. The estimation of the job dissatisfaction equation (or pay dissatisfaction equation) without the variables that capture adverse working conditions revealed that wage is not a statistically significant explanatory variable. The result supports the hypothesis of compensating differentials, since insignificance of the wage would follow from full wage compensation. On the other hand, the estimation of the job dissatisfaction model (or pay dissatisfaction model) without wage showed that work disamenities were still significant. This contradicts the hypothesis of compensating differentials. This is not surprising as such, because the fitted wage is not a statistically significant explanatory variable for the level of job dissatisfaction (Table 2).

These results point out that it is unlikely that reliable inferences on the hypothesis of compensating wage differentials can be drawn from these tests. At least, if one has data available on utility (or rather, proxies for it), wage, and work conditions, it is advisable to use all of them. In our case, it is clear that the conflicting conclusions are at least partly caused by the result that wage does not seem to be related to job satisfaction.

\section{Conclusions}

This study investigated the role of adverse working conditions in the determination of individual wages and the level of overall job satisfaction in the Finnish labour market. The potential influence of adverse working conditions on self-reported fairness of pay was considered as an alternative, indirect measure for job satisfaction.

Our reading of the evidence is that working conditions have a very minor role in the determination of individual wages in the labour market. In contrast, adverse working conditions substantially increase the level of job dissatisfaction and the perception of unfairness of pay at the workplace. 


\section{References}

Arabsheibani, G. R. and Marin, A. (2001). Self-selectivity bias with a continuous variable: potential pitfall in a common procedure. Applied Economics, 33: 1903-1910.

Blachflower, D. G. and Oswald, A. J. (1995). The Wage Curve. Cambridge MA: The MIT Press.

Brown, C. (1980). Equalizing differences in the labor market. The Quarterly Journal of Economics, 94: 113-134.

Clark, A. E. (1996). Job satisfaction in Britain. British Journal of Industrial Relations, 34: 189-217.

Clark, A. E. (2003). Looking for labour market rents with subjective data. Mimeo, DELTA.

Daniel, C. and Sofer, C. (1998). Bargaining, compensating wage differentials, and dualism of the labor market: theory and evidence for France. Journal of Labor Economics, 16: 546-575.

Dorman, P. (1996). Markets \& Mortality. Economics, Dangerous Work, and The Value of Human Life. Cambridge: Cambridge University Press.

Dorman, P. and Hagstrom, P. (1998). Wage compensation for dangerous work revisited. Industrial and Labor Relations Review, 52: 116-135.

Duncan, G. and Holmlund, B. (1983). Was Adam Smith right after all? Another test of the theory of compensating wage differentials. Journal of Labor Economics, 1: 366-389.

Fehr, E. and Gächter, S. (2000). Fairness and retalitation: The economics of reciprocity. Journal of Economic Perspectives, 14: 159-181. 
Freeman, R. (1978). Job satisfaction as an economic variable. American Economic Review, 68: 135-141.

French, M. T. and Dunlap, L. J. (1998). Compensating wage differentials for job stress. Applied Economics, 30: 1067-1075.

Gariety, B. S. and Shaffer, S. (2001). Wage differentials associated with flextime. Monthly Labor Review, 124: 68-75.

Godechot, O. and Gurgand, M. (2000). Quand les salariés jugent leur salaire. Economie et Statistique, 331: 3-24.

Gronberg, T. J. and Reed, W. R. (1994). Estimating workers' marginal willingness to pay for job attributes using duration data. Journal of Human Resources, 29: 911-931.

Herzog, H. W. and Schottmann, A. M. (1990). Valuing risk in the workplace: market price, willingness to pay, and the optimal provision of safety. Review of Economics and Statistics, 71: 463-470.

Hwang, H., Mortensen, D. T., and Reed, W. R. (1998). Hedonic wages and labor market search. Journal of Labor Economics, 16: 815-847.

Ilmakunnas, P. and Maliranta, M. (2003). The turnover of jobs and workers in a deep recession: evidence from the Finnish business sector. International Journal of Manpower, 24: 216-246.

Kawaguchi, D. (2002). Compensating wage differentials among self-employed workers: Evidence from job satisfaction scores. Discussion Paper No. 568. The Institute of Social and Economic Research Osaka University.

Kletzer, L.G. (1998). Job displacement. Journal of Economic Perspectives, 12: 115136. 
Lanfranchi, J., Ohlsson, H. and Skalli, A. (2002). Compensating wage differentials and shift work preferences. Economics Letters, 74: 393-398.

Lang, K. and Majumdar, S. (2003). The pricing of job characteristics when markets do not clear: theory and policy implications. Working Paper No. 9911. National Bureau of Economic Research.

Lalive, R. (2002), Do wages compensate for workplace amenities? Mimeo, University of Zurich.

Lehto, A.-M. and Sutela, H. (1999). Efficient, more efficient, exhausted. Findings of Finnish Quality of Work Life Surveys 1977-1997. Statistics Finland, SVT, Labour Market 1999:8.

Magnani, E. (2002). Product market volatility and the adjustment of earnings to risk. Industrial Relations, 41: 304-328.

Manning, A. (2003). Monopsony in Motion. Imperfect Competition in Labor Markets. Princeton: Princeton University Press.

McNabb, R. (1989). Compensating wage differentials: some evidence for Britain. Oxford Economics Papers, 41: 327-338.

Oi, W. Y. and Idson, T. L. (1999). Firm size and wages. In O. Ashenfelter and D. Card, D. (eds.), Handbook of Labor Economics, Volume 3B. Elsevier: Amsterdam.

Rosen, S. (1986). The theory of equalizing differences. In O. Ashenfelter and R. Layard (eds.): Handbook of Labor Economics, Volume 1. Elsevier: Amsterdam.

Sandy, R. and Elliott, R. F. (1996). Unions and risks: their impact on the level of compensation for fatal risk. Economica, 63: 291-309.

Stewart, M. B. (2004). Semi-nonparametric estimation of extended ordered probit models. Stata Journal, 4: 27-39. 
Stutzer, A. and Frey, B. S. (2003). Stress that doesn't pay: The commuting paradox. Working Paper No. 151. Institute for Empirical Research in Economics.

Van Praag, B. and Ferrer-I-Carbonell, A. (2004). Happiness Quantified. A Satisfaction Calculus Approach. Oxford: Oxford University Press.

Viscusi, W. K. (1993). The value of risks to life and death. Journal of Economic Literature, 31: 1912-1946.

Viscusi, W. K. and Aldy, J. E. (2003). The value of a statistical life: A critical review of market estimates throughout the world. Journal of Risk and Uncertainty, 27: 5-76.

Wei, X. (1999). Estimating British workers' demand for safety. Applied Economics, 31: $1265-1271$.

Webster, E. and Bainger, T. (2001). The importance of pecuniary and non-pecuniary rewards in job choice. Melbourne Institute Working Paper No. 18/01. 
Table 1. Estimation results for the wage equations.

\begin{tabular}{|c|c|c|c|}
\hline & $\begin{array}{l}\operatorname{Ln}(W A G E), \\
O L S\end{array}$ & $\begin{array}{l}\operatorname{Ln}(W A G E), \\
O L S\end{array}$ & $\begin{array}{l}\text { WAGECAT, } \\
\text { Interval } \\
\text { regression }\end{array}$ \\
\hline FEMALE & $\begin{array}{l}-0.194 \\
(4.16)^{* * *}\end{array}$ & $\begin{array}{l}-0.165 \\
(3.27)^{* * *}\end{array}$ & $\begin{array}{l}-0.199 \\
(9.62)^{* * *}\end{array}$ \\
\hline AGE_2 & $\begin{array}{l}0.615 \\
(6.35)^{* * *}\end{array}$ & $\begin{array}{l}0.612 \\
(6.34)^{* * *}\end{array}$ & $\begin{array}{l}0.329 \\
(7.89)^{* * *}\end{array}$ \\
\hline AGE_3 & $\begin{array}{l}0.799 \\
(7.80)^{* * *}\end{array}$ & $\begin{array}{l}0.803 \\
(7.88)^{* * *}\end{array}$ & $\begin{array}{l}0.416 \\
(9.43)^{* * *}\end{array}$ \\
\hline UNION & $\begin{array}{l}0.267 \\
(4.82)^{* * *}\end{array}$ & $\begin{array}{l}0.298 \\
(5.39)^{* * *}\end{array}$ & $\begin{array}{l}0.083 \\
(3.57)^{* * *}\end{array}$ \\
\hline SINGLE & $\begin{array}{l}-0.079 \\
(1.29)\end{array}$ & $\begin{array}{l}-0.079 \\
(1.29)\end{array}$ & $\begin{array}{l}-0.080 \\
(3.11)^{* * *}\end{array}$ \\
\hline SPOUSEWORK & $\begin{array}{l}0.063 \\
(1.63)\end{array}$ & $\begin{array}{l}0.045 \\
(1.18)\end{array}$ & $\begin{array}{l}0.013 \\
(0.77)\end{array}$ \\
\hline CHILDREN & $\begin{array}{l}-0.010 \\
(0.82)\end{array}$ & $\begin{array}{l}-0.008 \\
(0.69)\end{array}$ & $\begin{array}{l}0.002 \\
(0.45)\end{array}$ \\
\hline EDU_2 & $\begin{array}{l}0.135 \\
(2.18)^{* *}\end{array}$ & $\begin{array}{l}0.110 \\
(1.72)^{*}\end{array}$ & $\begin{array}{l}0.093 \\
(3.56)^{* * *}\end{array}$ \\
\hline EDU_3 & $\begin{array}{l}0.314 \\
(3.64)^{* * *}\end{array}$ & $\begin{array}{l}0.295 \\
(3.20)^{* * *}\end{array}$ & $\begin{array}{l}0.345 \\
(10.22)^{* * *}\end{array}$ \\
\hline EDU_4 & $\begin{array}{l}0.514 \\
(5.53)^{* * *}\end{array}$ & $\begin{array}{l}0.453 \\
(4.39)^{* * *}\end{array}$ & $\begin{array}{l}0.518 \\
(14.10)^{* * *}\end{array}$ \\
\hline EDUHUM & $\begin{array}{l}0.006 \\
(0.06)\end{array}$ & $\begin{array}{l}-0.063 \\
(0.56)\end{array}$ & $\begin{array}{l}0.019 \\
(0.52)\end{array}$ \\
\hline EDUBUS & $\begin{array}{l}0.099 \\
(1.52)\end{array}$ & $\begin{array}{l}0.076 \\
(1.03)\end{array}$ & $\begin{array}{l}0.092 \\
(3.59)^{* * *}\end{array}$ \\
\hline EDUTECH & $\begin{array}{l}0.028 \\
(0.43)\end{array}$ & $\begin{array}{l}0.010 \\
(0.14)\end{array}$ & $\begin{array}{l}-0.007 \\
(0.26)\end{array}$ \\
\hline EDUCARE & $\begin{array}{l}0.159 \\
(1.87)^{*}\end{array}$ & $\begin{array}{l}-0.002 \\
(0.02)\end{array}$ & $\begin{array}{l}0.100 \\
(2.98)^{* * *}\end{array}$ \\
\hline OVER1PROFS & $\begin{array}{l}-0.046 \\
(1.35)\end{array}$ & $\begin{array}{l}-0.048 \\
(1.42)\end{array}$ & $\begin{array}{l}-0.024 \\
(1.70)^{*}\end{array}$ \\
\hline SWITCHES & $\begin{array}{l}0.014 \\
(0.96)\end{array}$ & $\begin{array}{l}0.011 \\
(0.74)\end{array}$ & $\begin{array}{l}0.015 \\
(2.85)^{* * *}\end{array}$ \\
\hline UMOS1 & $\begin{array}{l}0.090 \\
(1.71)^{*}\end{array}$ & $\begin{array}{l}0.079 \\
(1.46)\end{array}$ & $\begin{array}{l}-0.038 \\
(1.58)\end{array}$ \\
\hline UMOS2 & $\begin{array}{l}-0.001 \\
(0.01)\end{array}$ & $\begin{array}{l}0.009 \\
(0.10)\end{array}$ & $\begin{array}{l}-0.073 \\
(2.14)^{* *}\end{array}$ \\
\hline UMOS3 & $\begin{array}{l}-0.337 \\
(3.14)^{* * *}\end{array}$ & $\begin{array}{l}-0.342 \\
(3.18)^{* * *}\end{array}$ & $\begin{array}{l}-0.061 \\
(1.71)^{*}\end{array}$ \\
\hline UMOS4 & $\begin{array}{l}-0.890 \\
(6.22)^{* * *}\end{array}$ & $\begin{array}{l}-0.874 \\
(6.21)^{* * *}\end{array}$ & $\begin{array}{l}-0.086 \\
(1.63)\end{array}$ \\
\hline TENURE & $\begin{array}{l}0.064 \\
(8.83)^{* * *}\end{array}$ & $\begin{array}{l}0.067 \\
(9.13)^{* * *}\end{array}$ & $\begin{array}{l}0.012 \\
(3.80)^{* * *}\end{array}$ \\
\hline TENURE $^{2}$ & $\begin{array}{l}-0.002 \\
(8.02)^{* * *}\end{array}$ & $\begin{array}{l}-0.002 \\
(8.39)^{* * *}\end{array}$ & $\begin{array}{l}-0.000 \\
(2.89)^{* * *}\end{array}$ \\
\hline SECONDJOB & $\begin{array}{l}0.140 \\
(1.37)\end{array}$ & $\begin{array}{l}0.121 \\
(1.15)\end{array}$ & $\begin{array}{l}-0.049 \\
(1.10)\end{array}$ \\
\hline FIXEDPAY & $\begin{array}{l}0.006 \\
(0.10)\end{array}$ & $\begin{array}{l}0.016 \\
(0.29)\end{array}$ & $\begin{array}{l}-0.075 \\
(2.96)^{* * *}\end{array}$ \\
\hline PIECERATE & $\begin{array}{l}-0.135 \\
(0.88)\end{array}$ & $\begin{array}{l}-0.107 \\
(0.68)\end{array}$ & $\begin{array}{l}-0.102 \\
(1.52)\end{array}$ \\
\hline TEMPORARY & $\begin{array}{l}-0.533 \\
(6.87)^{* * *}\end{array}$ & $\begin{array}{l}-0.512 \\
(6.53) * * *\end{array}$ & $\begin{array}{l}-0.093 \\
(3.19)^{* * *}\end{array}$ \\
\hline PART_TIME & $\begin{array}{l}0.055 \\
(0.66)\end{array}$ & $\begin{array}{l}0.058 \\
(0.68)\end{array}$ & $\begin{array}{l}-0.537 \\
(8.26)^{* * *}\end{array}$ \\
\hline
\end{tabular}




\begin{tabular}{|c|c|c|c|}
\hline NIGHT & $\begin{array}{l}0.122 \\
(0.87)\end{array}$ & $\begin{array}{l}0.166 \\
(1.14)\end{array}$ & $\begin{array}{l}0.177 \\
(2.74)^{* * *}\end{array}$ \\
\hline SHIFT & $\begin{array}{l}0.194 \\
(2.51)^{* * *}\end{array}$ & $\begin{array}{l}0.132 \\
(1.60)\end{array}$ & $\begin{array}{l}0.223 \\
(6.25) * * *\end{array}$ \\
\hline WEEKEND & $\begin{array}{l}0.430 \\
(0.79)\end{array}$ & $\begin{array}{l}0.497 \\
(0.89)\end{array}$ & $\begin{array}{l}-0.945 \\
(3.76)^{* * *}\end{array}$ \\
\hline MUCHOVERTIME & $\begin{array}{l}-0.081 \\
(0.87)\end{array}$ & $\begin{array}{l}-0.062 \\
(0.70)\end{array}$ & $\begin{array}{l}0.064 \\
(1.77)^{*}\end{array}$ \\
\hline NOBREAKS & $\begin{array}{l}-0.001 \\
(0.02)\end{array}$ & $\begin{array}{l}-0.025 \\
(0.43)\end{array}$ & $\begin{array}{l}-0.005 \\
(0.19)\end{array}$ \\
\hline OUTDOORS & $\begin{array}{l}0.129 \\
(1.75)^{*}\end{array}$ & $\begin{array}{l}0.148 \\
(1.91)^{*}\end{array}$ & $\begin{array}{l}-0.051 \\
(1.37)\end{array}$ \\
\hline HARM & $\begin{array}{l}0.018 \\
(0.44)\end{array}$ & $\begin{array}{l}0.016 \\
(0.41)\end{array}$ & $\begin{array}{l}-0.001 \\
(0.04)\end{array}$ \\
\hline HAZARD & $\begin{array}{l}0.014 \\
(0.35)\end{array}$ & $\begin{array}{l}0.025 \\
(0.66)\end{array}$ & $\begin{array}{l}0.021 \\
(1.31)\end{array}$ \\
\hline UNCERTAINTY & $\begin{array}{l}0.004 \\
(0.12)\end{array}$ & $\begin{array}{l}-0.005 \\
(0.15)\end{array}$ & $\begin{array}{l}0.014 \\
(0.90)\end{array}$ \\
\hline NOVOICE & $\begin{array}{l}-0.073 \\
(1.89)^{*}\end{array}$ & $\begin{array}{l}-0.078 \\
(2.06)^{* *}\end{array}$ & $\begin{array}{l}-0.064 \\
(4.07)^{* * *}\end{array}$ \\
\hline NEGLECT & $\begin{array}{l}-0.040 \\
(0.84)\end{array}$ & $\begin{array}{l}-0.022 \\
(0.49)\end{array}$ & $\begin{array}{l}-0.047 \\
(2.35)^{* *}\end{array}$ \\
\hline ATMOSPHERE & $\begin{array}{l}-0.196 \\
(3.03) * * *\end{array}$ & $\begin{array}{l}-0.169 \\
(2.61)^{* * *}\end{array}$ & $\begin{array}{l}-0.033 \\
(1.25)\end{array}$ \\
\hline CONFLICTS & $\begin{array}{l}0.033 \\
(0.49)\end{array}$ & $\begin{array}{l}0.056 \\
(0.87)\end{array}$ & $\begin{array}{l}0.027 \\
(0.95)\end{array}$ \\
\hline HEAVYPHYSIC & $\begin{array}{l}0.055 \\
(0.71)\end{array}$ & $\begin{array}{l}0.091 \\
(1.19)\end{array}$ & $\begin{array}{l}-0.034 \\
(0.91)\end{array}$ \\
\hline HEAVYMENTAL & $\begin{array}{l}0.004 \\
(0.06)\end{array}$ & $\begin{array}{l}-0.023 \\
(0.34)\end{array}$ & $\begin{array}{l}0.043 \\
(1.68)^{*}\end{array}$ \\
\hline MUCHCOMPUTER & $\begin{array}{l}0.046 \\
(0.84)\end{array}$ & $\begin{array}{l}0.060 \\
(1.06)\end{array}$ & $\begin{array}{l}0.043 \\
(2.07)^{* *}\end{array}$ \\
\hline DAYSTRAINING & $\begin{array}{l}0.006 \\
(1.64)\end{array}$ & $\begin{array}{l}0.007 \\
(1.92)^{*}\end{array}$ & $\begin{array}{l}0.004 \\
(2.45)^{* * *}\end{array}$ \\
\hline NOPROMOTION & $\begin{array}{l}0.020 \\
(0.50)\end{array}$ & $\begin{array}{l}0.022 \\
(0.58)\end{array}$ & $\begin{array}{l}-0.022 \\
(1.44)\end{array}$ \\
\hline DISCRIMINATION & $\begin{array}{l}0.049 \\
(1.36)\end{array}$ & $\begin{array}{l}0.035 \\
(0.98)\end{array}$ & $\begin{array}{l}0.007 \\
(0.48)\end{array}$ \\
\hline HIGHTEAM & $\begin{array}{l}-0.024 \\
(0.61)\end{array}$ & $\begin{array}{l}-0.001 \\
(0.02)\end{array}$ & $\begin{array}{l}-0.010 \\
(0.61)\end{array}$ \\
\hline TEAMPROBLEM & $\begin{array}{l}0.011 \\
(0.29)\end{array}$ & $\begin{array}{l}0.026 \\
(0.72)\end{array}$ & $\begin{array}{l}0.034 \\
(2.22)^{* *}\end{array}$ \\
\hline MANAGER & $\begin{array}{l}0.080 \\
(2.09)^{* *}\end{array}$ & $\begin{array}{l}0.076 \\
(1.98)^{* *}\end{array}$ & $\begin{array}{l}0.107 \\
(6.72)^{* * *}\end{array}$ \\
\hline SICKABSENCE & $\begin{array}{l}0.007 \\
(0.50)\end{array}$ & $\begin{array}{l}0.006 \\
(0.42)\end{array}$ & $\begin{array}{l}-0.011 \\
(1.34)\end{array}$ \\
\hline CONDITION & $\begin{array}{l}-0.001 \\
(0.07)\end{array}$ & $\begin{array}{l}0.001 \\
(0.08)\end{array}$ & $\begin{array}{l}0.011 \\
(2.03)^{* *}\end{array}$ \\
\hline PUBLIC & $\begin{array}{l}-0.054 \\
(0.84)\end{array}$ & $\begin{array}{l}-0.050 \\
(0.78)\end{array}$ & $\begin{array}{l}-0.008 \\
(0.32)\end{array}$ \\
\hline FIRMFOREIGN & $\begin{array}{l}0.039 \\
(0.54)\end{array}$ & $\begin{array}{l}0.000 \\
(0.01)\end{array}$ & $\begin{array}{l}0.091 \\
(3.42)^{* * *}\end{array}$ \\
\hline PSIZE2 & $\begin{array}{l}0.136 \\
(2.90)^{* * *}\end{array}$ & $\begin{array}{l}0.114 \\
(2.41)^{* *}\end{array}$ & $\begin{array}{l}0.113 \\
(5.86)^{* * *}\end{array}$ \\
\hline PSIZE3 & $\begin{array}{l}0.157 \\
(2.99)^{* * *}\end{array}$ & $\begin{array}{l}0.139 \\
(2.64)^{* * *}\end{array}$ & $\begin{array}{l}0.131 \\
(6.25)^{* * *}\end{array}$ \\
\hline PSIZE4 & $\begin{array}{l}0.232 \\
(3.66)^{* * *}\end{array}$ & $\begin{array}{l}0.209 \\
(3.14)^{* * *}\end{array}$ & $\begin{array}{l}0.171 \\
(6.18)^{* * *}\end{array}$ \\
\hline EMPGROWTH & $\begin{array}{l}0.076 \\
(1.43)\end{array}$ & $\begin{array}{l}0.064 \\
(1.18)\end{array}$ & $\begin{array}{l}0.035 \\
(1.70)^{*}\end{array}$ \\
\hline
\end{tabular}




\begin{tabular}{l|lll}
\hline FIRMUNSTABLE & -0.072 & -0.086 & -0.037 \\
& $(1.43)$ & $(1.76)^{*}$ & $(1.79)^{*}$ \\
FEMSHARE & 0.049 & 0.059 & -0.046 \\
& $(1.02)$ & $(1.16)$ & $(2.29)^{* *}$ \\
$\mathrm{UN}$ & -0.007 & -0.007 & -0.006 \\
& $(1.73)^{*}$ & $(1.71)^{*}$ & $(4.17)^{* * *}$ \\
Industry dummies & Yes & Yes & Yes \\
Occupation dummies & No & Yes & No \\
Observations & 2801 & 2801 & 2801 \\
R-squared & 0.41 & 0.46 & \\
\hline
\end{tabular}

Robust t statistics in parentheses. * significant at $10 \%$; ** significant at $5 \%$; *** significant at $1 \%$ 
Table 2. Estimation results for the dissatisfaction equations.

\begin{tabular}{|c|c|c|}
\hline & $\begin{array}{l}\text { DISSATISFACTION, } \\
\text { Ordered Probit }\end{array}$ & $\begin{array}{l}\text { PAYUNFAIR, } \\
\text { Ordered Probit }\end{array}$ \\
\hline FITTED WAGE & $\begin{array}{l}0.076 \\
(1.02)\end{array}$ & $\begin{array}{l}0.015 \\
(0.17)\end{array}$ \\
\hline FEMALE & $\begin{array}{l}-0.154 \\
(2.26)^{* *}\end{array}$ & $\begin{array}{l}0.024 \\
(0.37)\end{array}$ \\
\hline AGE_2 & $\begin{array}{l}-0.220 \\
(2.04)^{* *}\end{array}$ & $\begin{array}{l}0.216 \\
(2.10)^{* *}\end{array}$ \\
\hline AGE_3 & $\begin{array}{l}-0.298 \\
(2.43)^{* *}\end{array}$ & $\begin{array}{l}0.123 \\
(1.05)\end{array}$ \\
\hline UNION & $\begin{array}{l}0.028 \\
(0.41)\end{array}$ & $\begin{array}{l}0.165 \\
(2.57)^{* *}\end{array}$ \\
\hline SINGLE & $\begin{array}{l}0.152 \\
(1.97)^{* *}\end{array}$ & $\begin{array}{l}0.055 \\
(0.75)\end{array}$ \\
\hline SPOUSEWORK & $\begin{array}{l}0.137 \\
(2.43)^{* *}\end{array}$ & $\begin{array}{l}-0.003 \\
(0.05)\end{array}$ \\
\hline CHILDREN & $\begin{array}{l}-0.021 \\
(1.10)\end{array}$ & $\begin{array}{l}-0.007 \\
(0.38)\end{array}$ \\
\hline EDU_2 & $\begin{array}{l}0.066 \\
(0.79)\end{array}$ & $\begin{array}{l}0.054 \\
(0.71)\end{array}$ \\
\hline EDU_3 & $\begin{array}{l}0.084 \\
(0.71)\end{array}$ & $\begin{array}{l}0.030 \\
(0.26)\end{array}$ \\
\hline EDU_4 & $\begin{array}{l}0.071 \\
(0.52)\end{array}$ & $\begin{array}{l}0.000 \\
(0.00)\end{array}$ \\
\hline EDUHUM & $\begin{array}{l}0.103 \\
(0.81)\end{array}$ & $\begin{array}{l}-0.022 \\
(0.18)\end{array}$ \\
\hline EDUBUS & $\begin{array}{l}-0.023 \\
(0.27)\end{array}$ & $\begin{array}{l}-0.013 \\
(0.17)\end{array}$ \\
\hline EDUTECH & $\begin{array}{l}0.040 \\
(0.47)\end{array}$ & $\begin{array}{l}0.004 \\
(0.05)\end{array}$ \\
\hline EDUCARE & $\begin{array}{l}0.023 \\
(0.20)\end{array}$ & $\begin{array}{l}-0.073 \\
(0.67)\end{array}$ \\
\hline TENURE & $\begin{array}{l}0.017 \\
(1.58)\end{array}$ & $\begin{array}{l}0.000 \\
(0.02)\end{array}$ \\
\hline TENURE $^{2}$ & $\begin{array}{l}-0.001 \\
(1.88)^{*}\end{array}$ & $\begin{array}{l}0.000 \\
(0.46)\end{array}$ \\
\hline SECONDJOB & $\begin{array}{l}0.010 \\
(0.07)\end{array}$ & $\begin{array}{l}0.039 \\
(0.34)\end{array}$ \\
\hline FIXEDPAY & $\begin{array}{l}-0.009 \\
(0.12)\end{array}$ & $\begin{array}{l}0.050 \\
(0.73)\end{array}$ \\
\hline PIECERATE & $\begin{array}{l}-0.117 \\
(0.73)\end{array}$ & $\begin{array}{l}-0.114 \\
(0.71)\end{array}$ \\
\hline TEMPORARY & $\begin{array}{l}-0.045 \\
(0.47)\end{array}$ & $\begin{array}{l}0.223 \\
(2.35)^{* *}\end{array}$ \\
\hline PART_TIME & $\begin{array}{l}0.106 \\
(1.08)\end{array}$ & $\begin{array}{l}0.016 \\
(0.20)\end{array}$ \\
\hline NIGHT & $\begin{array}{l}0.045 \\
(0.15)\end{array}$ & $\begin{array}{l}-0.064 \\
(0.26)\end{array}$ \\
\hline SHIFT & $\begin{array}{l}-0.225 \\
(1.94)^{*}\end{array}$ & $\begin{array}{l}-0.161 \\
(1.47)\end{array}$ \\
\hline WEEKEND & $\begin{array}{l}-0.422 \\
(1.05)\end{array}$ & $\begin{array}{l}0.265 \\
(0.60)\end{array}$ \\
\hline MUCHOVERTIME & $\begin{array}{l}-0.283 \\
(2.49)^{* *}\end{array}$ & $\begin{array}{l}0.240 \\
(2.27)^{* *}\end{array}$ \\
\hline NOBREAKS & $\begin{array}{l}0.178 \\
(2.10)^{* *}\end{array}$ & $\begin{array}{l}0.317 \\
(3.83)^{* * *}\end{array}$ \\
\hline OUTDOORS & $\begin{array}{l}0.159 \\
(1.44)\end{array}$ & $\begin{array}{l}0.168 \\
(1.63)\end{array}$ \\
\hline
\end{tabular}




\begin{tabular}{|c|c|c|}
\hline HARM & $\begin{array}{l}0.208 \\
(3.59)^{* * *}\end{array}$ & $\begin{array}{l}0.215 \\
(3.74)^{* * *}\end{array}$ \\
\hline HAZARD & 0.032 & 0.134 \\
\hline & $(0.58)$ & $(2.52)^{* *}$ \\
\hline UNCERTAINTY & $\begin{array}{l}0.175 \\
(3.43) * * *\end{array}$ & $\begin{array}{l}0.053 \\
(1.11)\end{array}$ \\
\hline NOVOICE & $\begin{array}{l}0.100 \\
(1.83)^{*}\end{array}$ & $\begin{array}{l}-0.070 \\
(1.37)\end{array}$ \\
\hline NEGLECT & $\begin{array}{l}0.275 \\
(4.23)^{* * *}\end{array}$ & $\begin{array}{l}0.181 \\
(3.03)^{* * *}\end{array}$ \\
\hline ATMOSPHERE & $\begin{array}{l}0.219 \\
(2.43)^{* *}\end{array}$ & $\begin{array}{l}0.029 \\
(0.33)\end{array}$ \\
\hline CONFLICTS & $\begin{array}{l}0.096 \\
(0.87)\end{array}$ & $\begin{array}{l}0.014 \\
(0.14)\end{array}$ \\
\hline HEAVYPHYSIC & $\begin{array}{l}0.260 \\
(2.15)^{* *}\end{array}$ & $\begin{array}{l}0.239 \\
(2.00)^{* *}\end{array}$ \\
\hline HEAVYMENTAL & $\begin{array}{l}0.259 \\
(2.29)^{* *}\end{array}$ & $\begin{array}{l}0.154 \\
(1.52)\end{array}$ \\
\hline MUCHCOMPUTER & $\begin{array}{l}0.016 \\
(0.20)\end{array}$ & $\begin{array}{l}-0.173 \\
(2.55)^{* *}\end{array}$ \\
\hline DAYSTRAINING & $\begin{array}{l}-0.009 \\
(2.00)^{* *}\end{array}$ & $\begin{array}{l}0.002 \\
(0.56)\end{array}$ \\
\hline NOPROMOTION & $\begin{array}{l}0.292 \\
(5.36)^{* * *}\end{array}$ & $\begin{array}{l}0.145 \\
(3.05)^{* * *}\end{array}$ \\
\hline DISCRIMINATION & $\begin{array}{l}0.318 \\
(5.89)^{* * *}\end{array}$ & $\begin{array}{l}0.290 \\
(5.67)^{* * *}\end{array}$ \\
\hline HIGHTEAM & $\begin{array}{l}-0.043 \\
(0.76)\end{array}$ & $\begin{array}{l}-0.013 \\
(0.25)\end{array}$ \\
\hline TEAMPROBLEM & $\begin{array}{l}-0.025 \\
(0.47)\end{array}$ & $\begin{array}{l}-0.022 \\
(0.45)\end{array}$ \\
\hline MANAGER & $\begin{array}{l}-0.032 \\
(0.57)\end{array}$ & $\begin{array}{l}-0.044 \\
(0.82)\end{array}$ \\
\hline SICKABSENCE & $\begin{array}{l}-0.001 \\
(0.05)\end{array}$ & $\begin{array}{l}0.025 \\
(1.31)\end{array}$ \\
\hline CONDITION & $\begin{array}{l}-0.108 \\
(5.39)^{* * *}\end{array}$ & $\begin{array}{l}-0.004 \\
(0.23)\end{array}$ \\
\hline PUBLIC & $\begin{array}{l}-0.124 \\
(1.37)\end{array}$ & $\begin{array}{l}0.126 \\
(1.52)\end{array}$ \\
\hline FIRMFOREIGN & $\begin{array}{l}0.078 \\
(0.87)\end{array}$ & $\begin{array}{l}-0.150 \\
(1.68)^{*}\end{array}$ \\
\hline PSIZE2 & $\begin{array}{l}0.021 \\
(0.33)\end{array}$ & $\begin{array}{l}-0.034 \\
(0.58)\end{array}$ \\
\hline PSIZE3 & $\begin{array}{l}-0.010 \\
(0.14)\end{array}$ & $\begin{array}{l}-0.133 \\
(2.04)^{* *}\end{array}$ \\
\hline PSIZE4 & $\begin{array}{l}-0.030 \\
(0.28)\end{array}$ & $\begin{array}{l}-0.247 \\
(2.49)^{* *}\end{array}$ \\
\hline EMPGROWTH & $\begin{array}{l}-0.122 \\
(1.51)\end{array}$ & $\begin{array}{l}0.020 \\
(0.27)\end{array}$ \\
\hline FIRMUNSTABLE & $\begin{array}{l}0.178 \\
(2.52)^{* *}\end{array}$ & $\begin{array}{l}0.197 \\
(3.05)^{* * *}\end{array}$ \\
\hline FEMSHARE & $\begin{array}{l}0.042 \\
(0.63)\end{array}$ & $\begin{array}{l}-0.013 \\
(0.21)\end{array}$ \\
\hline UN & $\begin{array}{l}-0.006 \\
(1.09)\end{array}$ & $\begin{array}{l}-0.000 \\
(0.01)\end{array}$ \\
\hline Industry dummies & Yes & Yes \\
\hline Occupation dummies & No & No \\
\hline Observations & 2745 & 2734 \\
\hline
\end{tabular}

Robust $t$ statistics in parentheses. * significant at $10 \% ; * *$ significant at 5\%; *** significant at $1 \%$ The fitted wage is obtained from the wage equation that is reported in the second column in Table 1. 


\section{Appendix 1. Definitions of the variables.}

Variable

Dependent variables:

WAGE

WAGECAT

DISSATISFACTION

PAYUNFAIR

Personal background characteristics:

FEMALE
AGE_1
AGE_2
AGE_3
UNION
SINGLE
SPOUSEWORK
CHILDREN
EDU_1
EDU_2
EDU_3
EDU_4
EDUHUM
EDUBUS
EDUTECH
EDUCARE

Past labour market experience:

OVER1PROFS

SWITCHES

UMOS_1

UMOS_2

UMOS_3

UMOS_4

TENURE

TENURE

SECONDJOB

Payment systems:

FIXEDPAY

PIECERATE

Working time:

TEMPORARY

PART_TIME

NIGHT

SHIFT

WEEKEND

MUCHOVERTIME

Working conditions:

NOBREAKS

OUTDOORS

HARM

HAZARD

UNCERTAINTY

NOVOICE
Definition/measurement

Logarithm of hourly earnings that is calculated based on the annual earnings (FIM) obtained from tax registers and by using regular weekly hours from LFS.

Logarithm of the self-reported monthly wage groups (19 groups). Logarithm is taken from the lower limit of wage groups.

Dissatisfaction with current job, measured in four categories. Higher values mean that worker is more dissatisfied.

Notion about the fairness of pay in comparison with the remuneration paid in other occupations. Measured in five categories. Higher values mean an increase in the perception of unfairness.

$1=$ female, $0=$ male

Age between 15-24 $=1$, otherwise $=0$ (reference)

Age between $25-44=1$, otherwise $=0$

Age between $45-64=1$, otherwise $=0$

Member of trade union $=1$, otherwise $=0$

Not married $=1$, otherwise $=0$

Spouse is working $=1$, otherwise $=0$

The number of children under 18 living at home

Comprehensive education $=1$, otherwise $=0$ (reference)

Upper secondary or vocational education $=1$, otherwise $=0$

Polytechnic or lower university degree $=1$, otherwise $=0$

Higher university degree $=1$, otherwise $=0$

Field of education is humanities or teachers' education $=1$, otherwise $=0$

Field of education is business, law or social science $=1$, otherwise $=0$

Field of education is technical, natural science or computer science $=1$, otherwise $=0$

Field of education is health care, social work, etc. $=1$, otherwise $=0$

Has been in more than one distinctly different kind of occupations during his $/$ her life $=1$, otherwise $=0$ Number of job switches during the past five years

Number of unemployment months during the past five years 1- $6=1$, otherwise $=0$

Number of unemployment months during the past five years 7-12 $=1$, otherwise $=0$

Number of unemployment months during the past five years $13-24=1$, otherwise $=0$

Number of unemployment months during the past five years 25 or more $=1$, otherwise $=0$

Number of years in the current firm

TENURE squared

Has a second job $=1$, otherwise $=0$

Fixed monthly or hourly pay (including shift work supplement) $=1$, otherwise $=0$

Payment system is based on only piece-work or commission pay $=1$, otherwise $=0$

Fixed-term employment relationship $=1$, otherwise $=0$

Part-time work $=1$, otherwise $=0$

Night work $=1$, otherwise $=0$

Uninterrupted 3 -shift work $=1$, otherwise $=0$

Has weekend work $=1$, otherwise $=0$

Does almost daily overtime for which receives compensation $=1$, otherwise $=0$

Can take breaks or rest periods 'far too seldom' $=1$, otherwise $=0$

Does principally outdoor work $=1$, otherwise $=0$

At least one adverse factor that affects work 'very much' (includes heat, cold, vibration, draught, noise, smoke, gas and fumes, humidity, dry indoor air, dusts, dirtiness of work environment, poor or glaring lightning, irritating or corrosive substances, restless work environment, repetitive, monotonous movements, difficult or uncomfortable working positions, time pressure and tight time schedules, heavy lifting, lack of space, mildew in buildings) $=1$, otherwise $=0$

At least one factor is experienced as 'a distinct hazard' (includes accident risk, becoming subject to physical violence, hazards caused by chemical substances, radiation hazard, major catastrophe hazard, hazard of infectious diseases, hazard of skin diseases, cancer risk, risk of strain injuries, risk of succumbing to mental disturbance, risk of grave work exhaustion, risk of causing serious injury to others, risk of causing serious damage to valuable equipment or product) $=1$, otherwise $=0$

Work carries at least one insecurity factor (includes transfer to other duties, threat of temporary dismissal, threat of permanent dismissal, threat of unemployment, threat of becoming incapable of work, unforeseen changes) $=1$, otherwise $=0$

'Not at all' able to influence at least one factor in work (includes contents of tasks, order in which tasks are 
NEGLECT

ATMOSPHERE

CONFLICTS

HEAVYPHYSIC

HEAVYMENTAL

Use of computers:

MUCHCOMPUTER

Training, promotion, and discrimination:

DAYSTRAINING

NOPROMOTION

DISCRIMINATION

Work organization:

HIGHTEAM

TEAMPROBLEM

MANAGER

Health and absenteeism:

SICKABSENCE

CONDITION

Information about employer:

PUBLIC

FIRMFOREIGN

PSIZE_1

PSIZE 2

PSIZE 3

PSIZE 4

EMPGROWTH

FIRMUNSTABLE

FEMSHARE

Regional variable:

UN

Industry and occupation:

Industries

Occupations done, pace of work, working methods, division of tasks between employees, choice of working partners, equipment purchases) $=1$, otherwise $=0$

At least one supportive factor 'never' experienced in work (includes advice or help, support and

encouragement from superiors, support and encouragement from co-workers, feel of being valued member of work community, opportunity to plan work, opportunity to apply own ideas in work, feel of own work as productive and useful $)=1$, otherwise $=0$

Experiences at least one negative aspect of work atmosphere 'daily or almost daily' or positive aspect 'never' (includes negative aspects conflicts or argument with someone else in work community or with a customer, being subject or threatened by physical violence, use of unfriendly words or gestures by co-workers or superiors, and positive aspects praise for work from co-workers or customers, opportunities for learning new things and developing in one's occupation $)=1$, otherwise $=0$

At least one type of conflict appears in work unit 'a lot' (includes competitive spirit, conflicts between superiors and subordinates, conflicts between employees, conflicts between employee groups) $=1$, otherwis $=0$

Current tasks physically 'very demanding' $=1$, otherwise $=0$

Current tasks mentally 'very demanding' $=1$, otherwise $=0$

Individual uses computer most of the working day $=1$, otherwise 0

Number of days attended courses while being paid by employer during the last 12 months

Advancement opportunities in current workplace 'poor' $=1$, otherwise $=0$

Has fallen subject to at least one type of unequal treatment or discrimination in current workplace (includes time of hiring, remuneration, career advancement opportunities, access to training arranged by employer, receiving information, attitudes of co-workers or superiors) $=1$, otherwise $=0$

Works in teams 'almost all the time' or 'about three quarters of the time' $=1$, otherwise $=0$ There is at least one problematic aspect in the work group (includes 'totally untrue' that group selects its leader, group decides about division of responsibilities, productiveness of work improves in group work, or work pressure becomes evenly distributed, and 'totally true' that group work causes conflicts) $=1$, otherwise $=$

Tasks involve supervision of work of others or delegation of tasks $=1$, otherwise $=0$

Number of absences from work due to illness in the last 6 month

Self-assessment of working capacity. The variable is scaled from 0 (total inability to work) to 10 (top working capacity)

Employer is state or municipality $=1$, otherwise $=0$

Employer is private, mainly foreign-owned enterprise $=1$, otherwise $=0$

Size of plant under 10 employees $=1$, otherwise $=0$ (reference)

Size of plant 10-49 employees $=1$, otherwise $=0$

Size of plant 50-499 employees $=1$, otherwise $=0$

Size of plant over 499 employees $=1$, otherwise $=0$

The number of employees has increased in the plant during the past three years $=1$, otherwise $=0$

Financial situation is 'unstable' $=1$, otherwise $=0$

Share of females in the company is 'high' $=1$, otherwise $=0$

The regional unemployment rate based on 21 NUTS3-regions (Source: LFS by Statistics Finland).

14 industry dummies based on Standard Industry Classification by Statistics Finland

81 occupation dummies based on the classification of occupations by Statistics Finland 
Appendix 2. Descriptive statistics for the explanatory variables.

\begin{tabular}{|c|c|c|c|c|}
\hline Variable & Mean & Std. Dev. & Min & $\operatorname{Max}$ \\
\hline FEMALE & 0.53 & 0.50 & 0.00 & 1.00 \\
\hline AGE_2 & 0.56 & 0.50 & 0.00 & 1.00 \\
\hline AGE_3 & 0.36 & 0.48 & 0.00 & 1.00 \\
\hline UNION & 0.79 & 0.41 & 0.00 & 1.00 \\
\hline SINGLE & 0.18 & 0.38 & 0.00 & 1.00 \\
\hline SPOUSEWORK & 0.56 & 0.50 & 0.00 & 1.00 \\
\hline CHILDREN & 0.86 & 1.37 & 0.00 & 18.00 \\
\hline EDU_2 & 0.56 & 0.50 & 0.00 & 1.00 \\
\hline EDU_3 & 0.12 & 0.32 & 0.00 & 1.00 \\
\hline EDU_4 & 0.09 & 0.28 & 0.00 & 1.00 \\
\hline EDUHUM & 0.06 & 0.24 & 0.00 & 1.00 \\
\hline EDUBUS & 0.16 & 0.37 & 0.00 & 1.00 \\
\hline EDUTECH & 0.27 & 0.44 & 0.00 & 1.00 \\
\hline EDUCARE & 0.10 & 0.30 & 0.00 & 1.00 \\
\hline OVER1PROFS & 0.57 & 0.50 & 0.00 & 1.00 \\
\hline SWITCHES & 0.74 & 1.64 & 0.00 & 30.00 \\
\hline UMOS1 & 0.14 & 0.35 & 0.00 & 1.00 \\
\hline UMOS2 & 0.07 & 0.25 & 0.00 & 1.00 \\
\hline UMOS3 & 0.06 & 0.24 & 0.00 & 1.00 \\
\hline UMOS4 & 0.04 & 0.21 & 0.00 & 1.00 \\
\hline TENURE & 9.54 & 9.29 & 0.00 & 47.00 \\
\hline SECONDJOB & 0.03 & 0.17 & 0.00 & 1.00 \\
\hline FIXEDPAY & 0.84 & 0.37 & 0.00 & 1.00 \\
\hline PIECERATE & 0.02 & 0.16 & 0.00 & 1.00 \\
\hline TEMPORARY & 0.18 & 0.38 & 0.00 & 1.00 \\
\hline PART_TIME & 0.10 & 0.30 & 0.00 & 1.00 \\
\hline NIGHT & 0.01 & 0.10 & 0.00 & 1.00 \\
\hline SHIFT & 0.04 & 0.20 & 0.00 & 1.00 \\
\hline WEEKEND & 0.00 & 0.05 & 0.00 & 1.00 \\
\hline MUCHOVERTIME & 0.05 & 0.21 & 0.00 & 1.00 \\
\hline NOBREAKS & 0.10 & 0.30 & 0.00 & 1.00 \\
\hline OUTDOORS & 0.05 & 0.23 & 0.00 & 1.00 \\
\hline HARM & 0.29 & 0.45 & 0.00 & 1.00 \\
\hline HAZARD & 0.34 & 0.47 & 0.00 & 1.00 \\
\hline UNCERTAINTY & 0.58 & 0.49 & 0.00 & 1.00 \\
\hline NOVOICE & 0.67 & 0.47 & 0.00 & 1.00 \\
\hline NEGLECT & 0.23 & 0.42 & 0.00 & 1.00 \\
\hline ATMOSPHERE & 0.11 & 0.31 & 0.00 & 1.00 \\
\hline CONFLICTS & 0.06 & 0.24 & 0.00 & 1.00 \\
\hline HEAVYPHYSIC & 0.05 & 0.22 & 0.00 & 1.00 \\
\hline HEAVYMENTAL & 0.06 & 0.24 & 0.00 & 1.00 \\
\hline MUCHCOMPUTER & 0.12 & 0.32 & 0.00 & 1.00 \\
\hline
\end{tabular}




\begin{tabular}{l|rrrr}
\hline & & & & \\
DAYSTRAINING & 2.75 & 5.56 & 0.00 & 60.00 \\
NOPROMOTION & 0.62 & 0.48 & 0.00 & 1.00 \\
DISCRIMINATION & 0.30 & 0.46 & 0.00 & 1.00 \\
HIGHTEAM & 0.32 & 0.46 & 0.00 & 1.00 \\
TEAMPROBLEM & 0.42 & 0.49 & 0.00 & 1.00 \\
& & & & \\
MANAGER & 0.32 & 0.47 & 0.00 & 1.00 \\
SICKABSENCE & 0.65 & 1.17 & 0.00 & 17.00 \\
CONDITION & 8.62 & 1.37 & 0.00 & 10.00 \\
PUBLIC & 0.34 & 0.48 & 0.00 & 1.00 \\
FIRMFOREIGN & 0.07 & 0.26 & 0.00 & 1.00 \\
& & & & \\
PSIZE2 & 0.36 & 0.48 & 0.00 & 1.00 \\
PSIZE3 & 0.28 & 0.45 & 0.00 & 1.00 \\
PSIZE4 & 0.08 & 0.27 & 0.00 & 1.00 \\
EMPGROWTH & 0.11 & 0.31 & 0.00 & 1.00 \\
FIRMUNSTABLE & 0.16 & 0.37 & 0.00 & 1.00 \\
& & & & \\
FEMSHARE & 0.41 & 0.49 & 0.00 & 1.00 \\
UN & 17.08 & 4.74 & 11.80 & 29.30 \\
\hline
\end{tabular}


Appendix 3. Estimation of wage equation separately for females and males.

\begin{tabular}{|c|c|c|}
\hline & $\begin{array}{l}\text { Ln(WAGE), } \\
\text { OLS for } \\
\text { females }\end{array}$ & $\begin{array}{l}\text { Ln }(W A G E), \\
\text { OLS for males }\end{array}$ \\
\hline AGE_2 & $\begin{array}{l}0.463 \\
(3.52)^{* * *}\end{array}$ & $\begin{array}{l}0.710 \\
(5.06) * * *\end{array}$ \\
\hline AGE_3 & $\begin{array}{l}0.664 \\
(4.81)^{* * *}\end{array}$ & $\begin{array}{l}0.813 \\
(5.43)^{* * *}\end{array}$ \\
\hline UNION & $\begin{array}{l}0.269 \\
(3.41)^{* * *}\end{array}$ & $\begin{array}{l}0.284 \\
(3.69)^{* * *}\end{array}$ \\
\hline SINGLE & $\begin{array}{l}0.018 \\
(0.21)\end{array}$ & $\begin{array}{l}-0.105 \\
(1.15)\end{array}$ \\
\hline SPOUSEWORK & $\begin{array}{l}0.022 \\
(0.41)\end{array}$ & $\begin{array}{l}0.133 \\
(2.47)^{* *}\end{array}$ \\
\hline CHILDREN & $\begin{array}{l}-0.057 \\
(2.83)^{* * *}\end{array}$ & $\begin{array}{l}0.048 \\
(2.64)^{* * *}\end{array}$ \\
\hline EDU_2 & $\begin{array}{l}0.212 \\
(2.66)^{* * *}\end{array}$ & $\begin{array}{l}0.017 \\
(0.17)\end{array}$ \\
\hline EDU_3 & $\begin{array}{l}0.368 \\
(3.26)^{* * *}\end{array}$ & $\begin{array}{l}0.164 \\
(1.15)\end{array}$ \\
\hline EDU_4 & $\begin{array}{l}0.681 \\
(5.47) * * *\end{array}$ & $\begin{array}{l}0.299 \\
(2.07)^{* *}\end{array}$ \\
\hline EDUHUM & $\begin{array}{l}0.093 \\
(0.85)\end{array}$ & $\begin{array}{l}-0.134 \\
(0.64)\end{array}$ \\
\hline EDUBUS & $\begin{array}{l}0.082 \\
(1.05)\end{array}$ & $\begin{array}{l}0.157 \\
(1.21)\end{array}$ \\
\hline EDUTECH & $\begin{array}{l}-0.051 \\
(0.53)\end{array}$ & $\begin{array}{l}0.068 \\
(0.69)\end{array}$ \\
\hline EDUCARE & $\begin{array}{l}0.084 \\
(0.88)\end{array}$ & $\begin{array}{l}0.460 \\
(2.34)^{* *}\end{array}$ \\
\hline OVER1PROFS & $\begin{array}{l}-0.077 \\
(1.59)\end{array}$ & $\begin{array}{l}-0.011 \\
(0.23)\end{array}$ \\
\hline SWITCHES & $\begin{array}{l}-0.001 \\
(0.04)\end{array}$ & $\begin{array}{l}0.018 \\
(1.19)\end{array}$ \\
\hline UMOS1 & $\begin{array}{l}0.147 \\
(2.03)^{* *}\end{array}$ & $\begin{array}{l}0.011 \\
(0.15)\end{array}$ \\
\hline UMOS2 & $\begin{array}{l}0.028 \\
(0.20)\end{array}$ & $\begin{array}{l}-0.006 \\
(0.06)\end{array}$ \\
\hline UMOS3 & $\begin{array}{l}-0.255 \\
(1.59)\end{array}$ & $\begin{array}{l}-0.477 \\
(3.37)^{* * *}\end{array}$ \\
\hline UMOS4 & $\begin{array}{l}-1.052 \\
(5.13)^{* * *}\end{array}$ & $\begin{array}{l}-0.751 \\
(3.95)^{* * *}\end{array}$ \\
\hline TENURE & $\begin{array}{l}0.076 \\
(6.79)^{* * *}\end{array}$ & $\begin{array}{l}0.049 \\
(5.15)^{* * *}\end{array}$ \\
\hline TENURE $^{2}$ & $\begin{array}{l}-0.002 \\
(5.96)^{* * *}\end{array}$ & $\begin{array}{l}-0.001 \\
(4.67)^{* * *}\end{array}$ \\
\hline SECONDJOB & $\begin{array}{l}0.340 \\
(2.72)^{* * *}\end{array}$ & $\begin{array}{l}-0.018 \\
(0.13)\end{array}$ \\
\hline FIXEDPAY & $\begin{array}{l}-0.022 \\
(0.27)\end{array}$ & $\begin{array}{l}0.004 \\
(0.05)\end{array}$ \\
\hline PIECERATE & $\begin{array}{l}0.057 \\
(0.23)\end{array}$ & $\begin{array}{l}-0.166 \\
(0.92)\end{array}$ \\
\hline TEMPORARY & $\begin{array}{l}-0.384 \\
(3.82)^{* * *}\end{array}$ & $\begin{array}{l}-0.695 \\
(5.79)^{* * *}\end{array}$ \\
\hline PART_TIME & $\begin{array}{l}0.204 \\
(2.13)^{* *}\end{array}$ & $\begin{array}{l}-0.300 \\
(1.89)^{*}\end{array}$ \\
\hline NIGHT & 0.070 & 0.340 \\
\hline
\end{tabular}




\begin{tabular}{|c|c|c|}
\hline & $(0.36)$ & $(2.00)^{* *}$ \\
\hline SHIFT & 0.193 & 0.170 \\
\hline WFEKFND & $\begin{array}{l}(1.73)^{*} \\
0.671\end{array}$ & $\begin{array}{l}(1.59) \\
-1.058\end{array}$ \\
\hline WEEKEND & $(1.60)$ & $(0.92)$ \\
\hline MUCHOVERTIME & $\begin{array}{l}-0.054 \\
(0.39)\end{array}$ & $\begin{array}{l}-0.207 \\
(1.60)\end{array}$ \\
\hline NOBREAKS & $\begin{array}{l}-0.062 \\
(0.86)\end{array}$ & $\begin{array}{l}0.261 \\
(3.24)^{* * *}\end{array}$ \\
\hline OUTDOORS & $\begin{array}{l}0.212 \\
(1.22)\end{array}$ & $\begin{array}{l}0.089 \\
(1.14)\end{array}$ \\
\hline HARM & $\begin{array}{l}0.017 \\
(0.32)\end{array}$ & $\begin{array}{l}-0.005 \\
(0.09)\end{array}$ \\
\hline HAZARD & $\begin{array}{l}0.004 \\
(0.09)\end{array}$ & $\begin{array}{l}0.015 \\
(0.25)\end{array}$ \\
\hline UNCERTAINTY & $\begin{array}{l}0.014 \\
(0.29)\end{array}$ & $\begin{array}{l}-0.035 \\
(0.68)\end{array}$ \\
\hline NOVOICE & $\begin{array}{l}-0.073 \\
(1.42)\end{array}$ & $\begin{array}{l}-0.048 \\
(0.84)\end{array}$ \\
\hline NEGLECT & $\begin{array}{l}-0.093 \\
(1.43)\end{array}$ & $\begin{array}{l}-0.036 \\
(0.53)\end{array}$ \\
\hline ATMOSPHERE & $\begin{array}{l}-0.277 \\
(2.83)^{* * *}\end{array}$ & $\begin{array}{l}-0.075 \\
(0.99)\end{array}$ \\
\hline CONFLICTS & $\begin{array}{l}0.064 \\
(0.74)\end{array}$ & $\begin{array}{l}0.050 \\
(0.44)\end{array}$ \\
\hline HEAVYPHYSIC & $\begin{array}{l}-0.033 \\
(0.28)\end{array}$ & $\begin{array}{l}0.124 \\
(1.43)\end{array}$ \\
\hline HEAVYMENTAL & $\begin{array}{l}-0.035 \\
(0.37)\end{array}$ & $\begin{array}{l}0.049 \\
(0.56)\end{array}$ \\
\hline MUCHCOMPUTER & $\begin{array}{l}0.103 \\
(1.49)\end{array}$ & $\begin{array}{l}-0.005 \\
(0.06)\end{array}$ \\
\hline DAYSTRAINING & $\begin{array}{l}0.006 \\
(1.18)\end{array}$ & $\begin{array}{l}0.006 \\
(1.31)\end{array}$ \\
\hline NOPROMOTION & $\begin{array}{l}0.038 \\
(0.68)\end{array}$ & $\begin{array}{l}0.002 \\
(0.03)\end{array}$ \\
\hline DISCRIMINATION & $\begin{array}{l}0.013 \\
(0.25)\end{array}$ & $\begin{array}{l}0.080 \\
(1.54)\end{array}$ \\
\hline HIGHTEAM & $\begin{array}{l}-0.008 \\
(0.15)\end{array}$ & $\begin{array}{l}-0.052 \\
(0.95)\end{array}$ \\
\hline TEAMPROBLEM & $\begin{array}{l}-0.003 \\
(0.05)\end{array}$ & $\begin{array}{l}0.048 \\
(0.92)\end{array}$ \\
\hline MANAGER & $\begin{array}{l}0.070 \\
(1.35)\end{array}$ & $\begin{array}{l}0.108 \\
(1.95)^{*}\end{array}$ \\
\hline SICKABSENCE & $\begin{array}{l}0.030 \\
(1.40)\end{array}$ & $\begin{array}{l}-0.016 \\
(0.86)\end{array}$ \\
\hline CONDITION & $\begin{array}{l}0.030 \\
(1.69)^{*}\end{array}$ & $\begin{array}{l}-0.031 \\
(1.84)^{*}\end{array}$ \\
\hline PUBLIC & $\begin{array}{l}0.024 \\
(0.31)\end{array}$ & $\begin{array}{l}-0.142 \\
(1.43)\end{array}$ \\
\hline FIRMFOREIGN & $\begin{array}{l}0.141 \\
(1.23)\end{array}$ & $\begin{array}{l}-0.021 \\
(0.23)\end{array}$ \\
\hline PSIZE2 & $\begin{array}{l}0.114 \\
(1.88)^{*}\end{array}$ & $\begin{array}{l}0.094 \\
(1.30)\end{array}$ \\
\hline PSIZE3 & $\begin{array}{l}0.124 \\
(1.77)^{*}\end{array}$ & $\begin{array}{l}0.142 \\
(1.77)^{*}\end{array}$ \\
\hline PSIZE4 & $\begin{array}{l}0.209 \\
(2.34)^{* *}\end{array}$ & $\begin{array}{l}0.174 \\
(1.92)^{*}\end{array}$ \\
\hline EMPGROWTH & $\begin{array}{l}0.012 \\
(0.15)\end{array}$ & $\begin{array}{l}0.153 \\
(2.09)^{* *}\end{array}$ \\
\hline FIRMUNSTABLE & -0.072 & -0.051 \\
\hline
\end{tabular}




\begin{tabular}{l|ll}
\hline & $(1.15)$ & $(0.63)$ \\
FEMSHARE & 0.059 & 0.035 \\
$\mathrm{UN}$ & $(1.04)$ & $(0.37)$ \\
& -0.003 & -0.010 \\
Industry dummies & $(0.61)$ & $(1.78)^{*}$ \\
Occupation dummies & Yes & Yes \\
Observations & 1488 & No \\
R-squared & 0.40 & 1313 \\
\hline
\end{tabular}

Robust $t$ statistics in parentheses. $*$ significant at $10 \% ; * *$ significant at 5\%; *** significant at $1 \%$ 
Notes

${ }^{1}$ Unfortunately, the data that we are using does not contain obvious instruments to handle the issue of potential endogeneity of working conditions. Therefore, we focus on the investigation of the robustness of the reported results, instead.

${ }^{2}$ Van Praag and Ferrer-I-Carbonell (2004) summarize the literature on satisfaction.

${ }^{3}$ Duncan and Holmlund (1983) discover empirical evidence for the existence of compensating wage differentials in Sweden, which has somewhat similar labour market institutions to Finland's.

${ }^{4}$ We could assume that utility depends on consumption, which, in turn, depends on wage, but this generalisation is not essential here.

${ }^{5}$ The QWLS survey does not include information on actual accidents in the firms.

${ }^{6}$ Ilmakunnas and Maliranta (2003) document that plant-level worker turnover is strongly procyclical in Finland.

7 The (minimum) premium for daily overtime is $50 \%$ for the first two hours and $100 \%$ for each following hour in Finland. The premium for weekly overtime is $50 \%$, irrespective of the number of hours.

${ }^{8}$ The results from the interval regression (Table 1, Column 3) give a negative coefficient for weekend work. This is not an important result, because the number of workers that are engaged in weekend work is eight in the data. 